\title{
特集＼cjkstart国境水域における水産資源と水産業 Part I
}

\section{日中韓 3 力国の新漁業秩序と漁業調整}

\author{
片 岡 千賀之 \\ 長崎大学名誉教授
}

The new fisheries regime and fisheries adjustment among Japan, China, and Korea

\section{CHIKASHI KATAOKA}

Emeritus professor of Nagasaki University

\section{1. 本論の目的}

北東アジアに扔いて 200 カイリ体制は，1977 年にソ 連，日本，北朝鮮が 200 カイリ水域を設定して始まっ たが，日本の 200 カイリ水域は中国，韓国には適用し なかったので，設定海域が限られていた。その日中韓が 200 カイリ体制に移行したのは, 1996 年に国連海洋法 条約を批准し，それぞれ新しく漁業協定を結んで，それ が発効する 1999 2001 年のことである。新漁業秩序が スタートして数年間は経過的措置がとられ，確立するの は 2005 年前後である。

北東アジアに打ける 200 カイリ体制への全面移行は 遅れたし，変則的な形となっている。その理由は，地域 には社会体制が異なる国家，分断国家があり，領土問題 が存在するので，島の領有権，大陸棚や EEZ（排他的 経済水域）の境界画定の問題と切り離して, 新漁業秩序 を形成したからである。

本論は, 日中韓に打ける新漁業秩序の形成過程, 性格 と特徵, 課題について考察することを目的とする。日中 韓の漁業関係は, 海域別にいうと日本海は日韓, 東シナ 海・黄海は日中韓 3 力国がかかわるが，本稿では東シ ナ海・黄海に焦点をあてる。

\section{200 カイリ体制導入の経過}

1977 年に米ソを始姺進国の多くが 200 カイリ水域 （名称は漁業水域または EEZ）を設定して 200 カイリ時 代が始まった。日本もこの時に 200 カイリ漁業水域を 設定したが，韓国，中国とはこれまでの関係を続けるた めに, 東経 135 度以西の日本海, 東シナ海には設定し ないし，韓国，中国漁船には適用しないとした。つま り, 日本の 200 カイリ水域設定は, 同年に 200 カイリ 水域を設定し，日本漁船を規制したソ連に対抗するため であった。

遠洋漁業が発達し, 外国の近海に出漁していた日本は, 200 カイリ制によって締め出されることになるので，本
心は反対であった。日本と韓国, 日本と中国との間に漁 業協定が結ばれていて, 韓国, 中国の近海に規制水域を 設定していたが，それでも200カイリ制に比べれば漁 業の自由があった。一方, 韓国, 中国の漁業は未発達 で, 日本近海に出漁することはなかった。領土問題の他 に，こうした背景があって日本の 200 カイリ水域の設 定は，変則的な形をとったのである。

ところが，その後，1970 年代に韓国，1980 年代に中 国の漁業が急速に発展し, 沖合に進出して日本漁船を圧 迫し, 日本近海にまで出漁するようになった。漁業勢力 の逆転に直面して, 日本は 200 カイリ制反対から全面 適用（韓国, 中国漁船に対しても適用）へと態度を変化 させた。国連海洋法条約の成立・発効がこの变化を正当 化した。

\section{3. 新漁業秩序の形成}

日中韓が新漁業秩序に向けて動き出したのは，3 カ国 が 1996 年に国連海洋法条約を批准し，EEZ を設定して からである。領土問題 (日韓の竹島, 日中の尖閣諸島), 大陸棚の境界，領海や EEZ を測る基線の引き方をめぐ る対立があって, 境界画定に関する協議と切り離した形 で漁業協議が進められた。数年間を費やして結ばれた新 漁業協定が発効するのは, 日韓が 1999 年 1 月, 日中が 2000 年 6 月, 中韓が 2001 年 6 月であり, その後, さ らに数年間は経過的措置がとられた。

漁業協議が長引き，新漁業協定の発効が遅れた背景に は, 漁業勢力の違いによる利害対立があった。 3 力国の 沖合漁業の勢力は, かつての日本 $>$ 韓国 $>$ 中国という序 列が完全に逆転して, 中国 $>$ 韓国 $>$ 日本となり, その格 差が急激に開いた。すなわち，漁業協議では，中国は自 国の漁業が大きく規制されるため, 協議の引き延ばし, 相手国水域への入漁の確保, 共同利用水域(名称は様々, EEZ の境界画定ができず， 2 力国の共同利用とする水 域。取締りは自国漁船のみを対象とする）を広くするこ 
と，手厚い経過的措置を主張して打撃の緩和を図った。 反対に漁業勢力が最も弱くなった日本は, 韓国, 中国ど ちらに対しても新協定を早期に締結し，自国水域から外 国漁船を規制・排除して資源や自国漁業の保護，とくに 競合の著しい底魚漁業（底魚を対象とする漁業，底电網 が代表）の存続を目指した。韓国は日本と中国との中間 に位置し，漁業勢力も中間にあるので，その立場は二律 背反的で，中国に対しては規制の強化を，日本に対して は規制の緩和を主張した。中国，韓国とも漁業勢力の序 列が変わったことで, 漁業規制に対する主張が従来のそ れと反対になった。

漁業協議では協定の実施時期, 協定の対象水域（協定 水域), 相互入漁がセットで話し合われ, 妥協が図られ た。

\section{4. 協定水域の設定}

各々の新漁業協定は，各国の $\mathrm{EEZ}$ を設定する権利を 認め，双方が主張する範囲が重なる海域は両国の共同利 用水域とした。図 1 で示すとおり, 共同利用水域は, 日韓では日本海に北部暫定措置水域，東シナ海に南部暫 定措置水域が設けられた。中韓では，黄海に架空の中間 線を引き，それを軸に左右の面積が同じになるように暫 定措置水域と過渡水域を設定した。過渡水域は協定発効

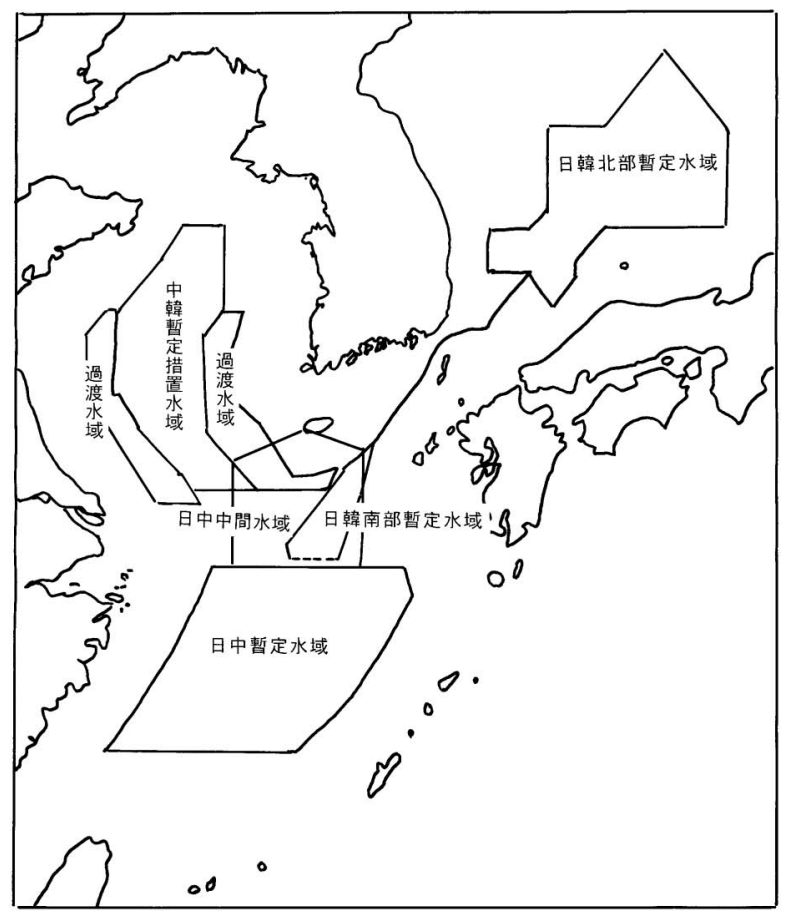

図 1 日中韓の新漁業体制関係図 資料：水産庁 注 1 : 中韓の過渡水域は 2005 年に両国の経済水域に 編入された。

2: 中韓の現行操業維持水域は省略した。

3 : 日韓南部暫定措置水域の範囲は韓国の地図と異 なる。
4 年後に両国の EEZ に編入するとした。日中は東シナ 海に広い範囲の暫定措置水域を設け, また台湾問題, 領 土問題を避けるために北緯 $27^{\circ}$ 以南は新漁業協定の適用 除外とした。

東シナ海・黄海では各国の EEZ と 2 力国の共同利用 水域がモザイク状になり，そのうえその一部は重複して いる。さらに, EEZ や共同利用水域に覆い被さる形で 日中の中間水域, 中韓の現行操業維持水域が設定されて, 200 カイリ規制に伴う中国, 韓国の打撃を緩和する措置 がとられている。こうしたこともあって，共同利用水域 に打協定国以外の国の漁船に対する入漁許可と取締 り権限は曖昧である。

\section{EEZ の相互入漁之漁獲割当て}

東シナ海・黄海では共同利用水域が広くとられた分, 各国の EEZ の幅は狭くなった。各国は EEZ 内の資源 水準を上回る漁獲能力を有し, 外国漁船に漁獲させるだ けの余利はないが，従来の経過や実績を考慮して相互入 漁措置をとった。相互入漁の漁獲割当てをめぐっても, 漁業勢力が弱い国は資源に余裕がないことを楯に割当量 を少なくし，等量化を主張したのに対し，漁業勢力が強 い国は実績確保と等量にする時期の先延ばしを図った。 妥結点は, 漁業勢力が弱い国を基準にして, 数年のうち に漁獲割当量を等量にすることであった。

表 1 に日韓, 日中の入漁許可隻数と漁獲割当量の推 移を示した（東シナ海・黄海だけでなく全海域）。それ 以前の実績（推定）に対する初年度の割当量は, 日韓で は韓国は約 20 万トンに対し約 15 万トンに，中韓では 中国は約 50 万トンに対し約 11 万トンに，それぞれ大 幅に削られている。実際には，共同利用水域で操業する ことができるので，実績（推定）との差がすべて削減さ れたわけではないが，それにしても漁業勢力が強い国の 打撃は大きい。日中では共同利用水域が広くとられたこ ともあって当初から割当量の差は小さい。

漁獲割当ての等量化は, 漁業勢力が強い国への割当量 を減らすことから始まり, 次いで資源の減少が著しい底 魚, 自国の漁業とトラブルを起こす漁業抢よび TAC (漁獲可能量) 管理をしている魚種の割当量を削減する 形で進んだ。日韓の例でいえば，韓国への割当ては，日 本が TAC 管理をしている底魚のスケトウダラ，ズワイ ガニ漁業がまずゼロになり，次いでかごと刺網がトラブ ルを理由に消滅している。

漁獲割当ての等量化は, 日韓, 日中ともに 2002 年に 実現している。入漁許可隻数についても日韓は 2002 年 から，日中は 2007 年から同数になった。漁獲割当ては 等量からさらに縮小均衡へ進んでいる。日中で, 中国へ の割当てが 2005 年に激減したのは経過的措置が終了し たことによる。

入漁実績はかなり低い。共同利用水域が広いので，そ 
表 1 日韓, 日中の相互入漁（入漁許可隻数と漁獲割当量の推移）

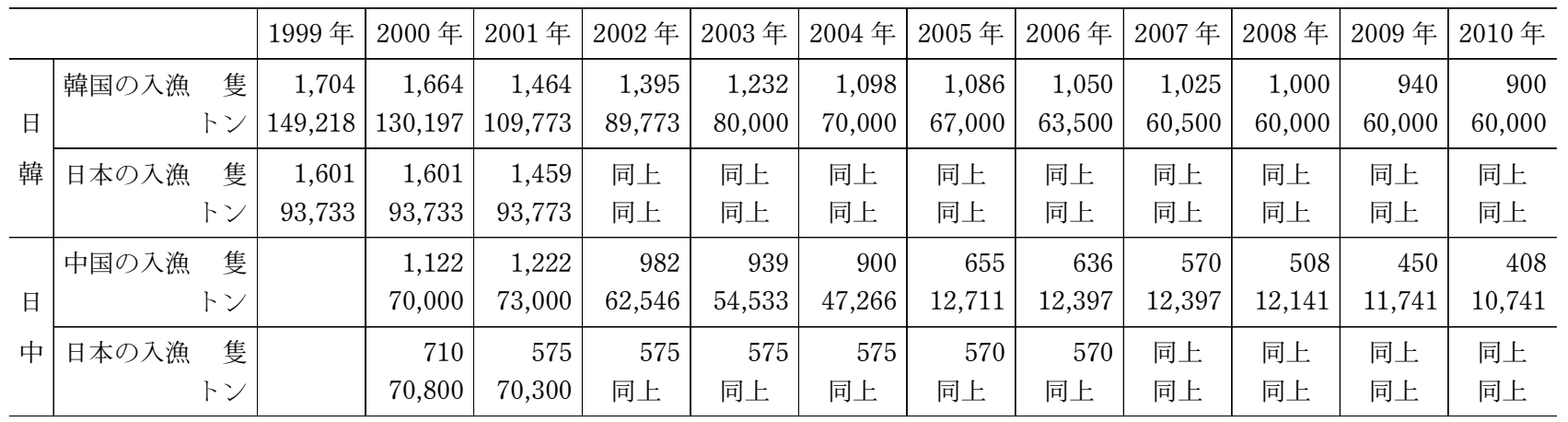

資料 : 水産庁

注：日中の 2000 年は $6 \sim 12$ 月の半年間。

の先の相手国水域に入漁することの得失を踏をえた結果 といえる。入漁実績が低いといっても, 漁業勢力が強い 国の方が高いし, 浮魚漁業（浮魚を対象とする漁業, ま き網が代表）は変動が大きく, 底魚漁業は比較的高い傾 向にある。入漁実績が低いので, 漁獲割当ての縮小均衡 が成り立ちやすいといえる。

共同利用水域は，相手国の取締りを受けないので，漁 業勢力が強い国の独占度が高まっている。共同利用水域 の資源管理は, 漁業勢力が強い国の抵抗で遅々として進 まなかったが，日中では国連海洋法条約を批准した 1996 年の水準に凍結する措置がとられた。すなわち, 中国は漁船 2 万隻, 漁獲量 210 万トンに対し, 日本は 1,000 隻, 10 万トンを上限とした。東シナ海の沖合で は日中の漁業勢力の差はこれほど大きかった。その後, 2010 年は中国は約 18,500 隻，約 176 万トン，日本は 800 隻, 約 11 万トンとなったに過ぎない。それ以外の 日韓と中韓の共同利用水域では漁船隻数, 漁獲量ともに 規制されていない。

\section{6. まとめと課題}

新漁業秩序は, 2 力国間の新漁業協定で構成されてい るが，EEZの他に共同利用水域などを設け，しかもそ れらが重複したり，管轄権が暧昧であったりして変則的 である。このことは 3 力国が向かい合う東シナ海・黄 海で著しく, 東シナ海・黄海全体からすると整合性のあ
る一体的な管理体系とはなっていない。

3 力国の EEZ 内では相互入漁が行われ, 許可隻数招 よび漁獲割当量とも等量化が目指され, さらに漁業勢力 が弱い国の状況に合わせる形で縮小均衡に向かってい る。縮小均衡がどこまで進むかは, 相互入漁によって広 い漁場を確保することが合理的な浮魚の漁獲割当てがど こまで進むかが一つの目安になると思われる。

共同利用水域での漁業は, 規制が緩やかで, 乱獲と資 源の減少が進行し, 漁業勢力が強い国が漁場を独占的に 利用している。そこでの共同管理は, 資源が境界を越え て回遊, 分布するので, 2 力国間だけではなく, 関係国 （現実的には日中韓 3 力国）が一堂に会して協議するの が望ましい。資源を持続的に利用するという共通の理念 を基礎にして, 浮魚 (回遊性魚種) は相互入漁, 底魚 （定着性魚種）は自国管轄水域（EEZ おちよび共同利用水 域）内とするなど，合理的な漁業調整が求められる。

新漁業秩序への移行とともに自国周辺水域への漁業依 存度が高まり, 各国は漁獲量規制や漁獲努力量の削減な ぞ漁業管理を強化している。TAC 管理は日本と韓国 が, 減船事業は韓国と中国が実施している。中国は夏季 休漁制を大規模に実施している。漁業管理は各国個別に 行われており, 漁業管理の効果を高めるには, 共通課題 での国際連携, 共同利用水域を含めた管理が不可欠であ る。 